\title{
Religious Denomination, Religiosity, Religious Attendance, and Cancer Prevention. A Systematic Review
}

\section{Benedikt Kretzler \\ Hans-Helmut König (D) \\ Linéa Brandt \\ Helene Rabea Weiss \\ André Hajek (D)}

Department of Health Economics and Health Services Research, University Medical Center Hamburg-Eppendorf, Hamburg, Germany
Correspondence: Benedikt Kretzler Department of Health Economics and Health Services Research, University Medical Center Hamburg-Eppendorf, Martinistraße 52, Hamburg, 2025I, Germany

Tel +494074I 024 I6I

Fax +49 40741040261

Email b.kretzler.ext@uke.de

\begin{abstract}
Recent research highlighted the influence of religion among health outcomes. To the best of our knowledge, there is no systematic review that summarizes the evidence on the relationship between religious factors and the utilization of cancer screenings. Therefore, this article aims to list the findings about the influence of religious denominations, the importance of religion in one's life, and religious practices, such as church attendance on the utilization of cancer screenings. PubMed, PsycInfo and CINAHL were searched using a predefined algorithm in June 2020. We included observational studies that examined the association between religion and cancer screening use and employed appropriate items to quantify these key variables. Study selection, data extraction and quality assessment were performed independently by two reviewers. We detected $n=27$ studies that fulfilled the inclusion criteria. Hereby, $\mathrm{n}=16$ used data from the United States. Most of the studies that were included in our review found a positive association between religious attendance and cancer screening utilization. There was mixed evidence concerning religious denomination as well as religiosity and use of cancer screenings. The studies suggest that religious factors are related to the utilization of cancer screenings. The findings of this systematic review may be helpful to resolve the underuse of cancer screenings by revealing at-risk-groups.
\end{abstract}

Keywords: spirituality, religiosity, cancer screening, preventive medicine, religious denomination, systematic review

\section{Introduction}

These days, cancer is one of the most urgent health problems worldwide: In 2018, it caused approximately 9.6 million deaths. Moreover, its prevalence has risen within the past years, ${ }^{1}$ an issue that might become even more severe due to demographic ageing. ${ }^{2}$ At the same time, a rise in cancer patients' survival rates is observable, ${ }^{3}$ a development that preventive health care has strongly contributed to. ${ }^{4}$ Generally, prevention is classified into three groups: Primary prevention aims to reduce the prevalence of an illness; secondary prevention seeks to facilitate a timely detection; and tertiary prevention aims to anticipate possible dangers after the disease's detection..$^{5}$ Among cancer prevention, some examples for secondary strategies are cervical screenings and mammograms. Usually, these services are supported by state health systems, as they are proven to be effective.$^{6-8}$ In Germany, all these screenings are covered by statutory health insurances. Despite these efforts, the use of preventive cancer medicine is rather low, ${ }^{9}$ compared to the guidelines of the World Health Organization which were developed by Wilson and Jungner. ${ }^{10}$ 
To tackle the current underuse of cancer screenings in various countries, ${ }^{9,11}$ research has focused on the determinants of utilization, often relying on the Andersen model of health care utilization. ${ }^{12}$ This theoretical framework groups the independent variables into three different categories, which are predisposing characteristics (eg, age and gender), enabling resources (eg, income and type of health insurance), and need factors (eg, health status). Among the predisposing and enabling categories, a higher age, ${ }^{13-15}$ being female, ${ }^{9}$ and better educated ${ }^{16}$ were revealed to increase the probability of cancer screening utilization. However, these results are not undisputed, as a number of studies identified contrary effects among age and gender. ${ }^{17,18}$ Apart from that, there are also need factors that are related to the use of cancer screenings: A poor health status, ${ }^{17}$ health conditions ${ }^{13}$ and a family cancer history ${ }^{19}$ are positively associated with the utilization of preventive cancer screenings. Some other studies, particularly those who focus on psychological factors, rely on the health belief model. ${ }^{20}$ They stated that a better knowledge of the disease ${ }^{21}$ and decreased loneliness, higher cognitive well-being or self-esteem and lower social exclusion were associated with higher cancer screening utilization. ${ }^{22}$

Several studies have shown an association between religion, which usually is classified as a predisposing variable in the Andersen model of health care utilization, and the use of preventive medicine, ${ }^{23,24}$ as well as the use of cancer screenings. ${ }^{25-31}$ This could also contribute to explaining the lower cancer mortality among people who frequently visit worships. ${ }^{32}$ However, findings regarding the utilization often differ, as some studies found religion to be positively associated with secondary preventive cancer medicine utilization, ${ }^{28}$ while some did not reveal a significant association, ${ }^{31}$ and some even revealed a negative relationship. ${ }^{25}$ The uncertainty about the influence of religion on cancer screening use is further increased by the diverging pathways that one could imagine between those two factors: On the one hand, the social and integrative aspect of religion may enhance screening rates among religious individuals, as a higher social support is associated with increased utilization of preventive health services. ${ }^{33,34}$ Furthermore, it is hypothesized that religious individuals score higher among personality traits such as conscientiousness, which are also related to an increased use of preventive cancer medicine. ${ }^{35}$ On the other hand, highly religious individuals may have tendencies to mistrust academic medicine and therefore have decreased levels of preventive services utilization. ${ }^{36}$ Though, to the best of our knowledge, there is no review that systematically synthesized the evidence on the association between religion and the utilization of preventive cancer screenings. Therefore, our aim was to summarize the existing findings of observational studies (both cross-sectional and longitudinal). Such a review might be helpful to identify populations who are at risk of underusing cancer screenings, as religion is associated with determinants of such an underuse: A stronger orientation towards religion has been shown to tackle lacks of knowledge of preventive health services, ${ }^{37}$ which are among the most important barriers to cancer screening uptake. ${ }^{15}$ In addition, our review could help to clarify whether religious environments and religious groups are appropriate target places for interventions, such as information campaigns about cancer screenings.

\section{Materials and Methods}

Our systematic review is in accordance with the Preferred Reporting Items for Systematic Reviews and MetaAnalysis Protocols guidelines. ${ }^{38}$ It is registered with the International Prospective Register of Systematic Reviews (PROSPERO, registration number: CRD42021229222).

\section{Search Strategy and Selection Criteria}

In June 2020, we searched three databases (PubMed, PsycInfo and CINAHL) for relevant literature. Therefore, we used a search algorithm which is displayed in Table 1.

The screening was carried out in a two-step process: At first, we performed a title-abstract screening, and afterwards, the articles that had passed were reviewed in full. Both the title-abstract screening (LB, BK) and the full-text screening (HRW, BK) were carried out independently by two reviewers and relied on the inclusion and exclusion criteria, which are provided in the following paragraphs. Finally, the reference lists of the studies that are included in this systematic review were investigated as well. Disagreements between the two reviewers were resolved through discussion or by consulting a third party (AH).

We included observational studies (both cross-sectional and longitudinal) reporting the association between any kind of religious dimensions, based on Glock's classification, ${ }^{39}$ and cancer screening.

We excluded:

- studies not considering the relationship between religion and cancer screening 
Table I Search Algorithm

\begin{tabular}{|c|c|}
\hline$\# 1$ & Religio*[Title/Abstract] \\
\hline$\# 2$ & Faith[Title/Abstract] \\
\hline \#3 & Spiritualit*[Title/Abstract] \\
\hline$\# 4$ & \#I OR \#2 OR \#3 \\
\hline$\# 5$ & Preventive health care[Title/Abstract] \\
\hline \#6 & Preventive health service*[Title/Abstract $]$ \\
\hline \#7 & Cancer screening[Title/Abstract] \\
\hline$\# 8$ & Melanoma screening[Title/Abstract] \\
\hline \#9 & Colonoscopy[Title/Abstract] \\
\hline$\# 10$ & Pap[Title/Abstract $]$ \\
\hline \#II & Mammography[Title/Abstract] \\
\hline$\# 12$ & FOBT[Title/Abstract] \\
\hline$\# 13$ & Guaiac[Title/Abstract] \\
\hline$\# 14$ & CRC screening[Title/Abstract] \\
\hline$\# 15$ & Cervical screening[Title/Abstract] \\
\hline$\# 16$ & Breast exam[Title/Abstract] \\
\hline$\# 17$ & Flexible sigmoidoscopy[Title/Abstract] \\
\hline$\# 18$ & PSA[Title/Abstract] \\
\hline$\# 19$ & $\begin{array}{l}\# 5 \text { OR \#6 OR \#7 OR \#8 OR \#9 OR \#10 OR \#II OR \#12 } \\
\text { OR \#I2 OR \#I3 OR \#14 OR \#I5 OR \#16 OR \#I7 OR \#18 }\end{array}$ \\
\hline$\# 20$ & \#3 AND \#19 \\
\hline
\end{tabular}

- studies exclusively examining a specific sample (eg, sects or ethnic minorities)

- study design not observational

- studies not published in German or English

- studies not published in scientific, peer-reviewed journals.

We did not apply any restrictions concerning time or place of an article. Our inclusion and exclusion criteria were pretested by utilizing them for the first 100 articles of the title-abstract screening. However, they were not changed afterwards.

\section{Data Extraction and Analysis}

The data extraction was performed by one reviewer (BK) and cross-checked by another one (AH). It included information about a study's time and region, assessment of main variables, study design, sample, and key results regarding the relationship between religion and cancer screening utilization.

\section{Quality Assessment}

Unfortunately, there is no "mainstream" quality assessment tool for studies regarding the utilization of preventive health services, or even health care use in general. For our purposes, we used the checklist introduced by Stuhldreher et $\mathrm{al}^{40}$ in the improved version provided by Hohls et al. ${ }^{41}$ The quality assessment was also performed by two reviewers (HRW, BK). Again, rating differences between the reviewers were resolved through discussion or by involving a third party $(\mathrm{AH})$.

\section{Results}

In the following sections, we describe the results of this systematic review separately for religious denomination, religiosity, and religious attendance. This classification is orientated towards the five dimensions of religion defined by Glock, ${ }^{39}$ with the dimension of belief being represented by denomination, practice by attendance and feeling by religiosity. Furthermore, one study explicitly aimed to examine religious salience, ${ }^{26}$ the fourth of Glock's dimensions. Finally, religious exclusivity, which is also called "dogmatism", ${ }^{42}$ is not represented, as it was not investigated regarding its link to cancer screening utilization. The key findings are presented in the text and in Table 2.

\section{Overview: Included Studies}

The screening process is displayed in Figure 1, using the PRISMA 2009 Flow Diagram. ${ }^{43}$ After the title-abstract screening, full texts were pending to be assessed for eligibility. Out of these, $n=27$ studies were included in our final sample. ${ }^{23,25-31,44-62}$ Three of the excluded ones were not observational. Furthermore, nine other studies had to be excluded because they did not report any relationship between religion and cancer screening utilization. One article investigated religion as a perceived barrier to cancer screening but did not regard its impact on cancer screening utilization. Regarding our inclusion and exclusion criteria, no articles had to be excluded because they were not employing appropriate tools to quantify the key variables, only examining a specific sample, or were published in non-scientific journals or not in English or German language. 
Table 2 Key Findings

Religious Denominations (Ref: Not Being Religious or Belonging to Another Religious Group)

\begin{tabular}{|c|c|c|c|c|c|c|c|c|c|c|c|}
\hline & & & $\begin{array}{l}\text { Mammogram or } \\
\text { Clinical Breast } \\
\text { Examination }\end{array}$ & $\begin{array}{l}\text { Pap } \\
\text { Smear }\end{array}$ & $\begin{array}{l}\text { Self-Breast } \\
\text { Examination }\end{array}$ & $\begin{array}{l}\text { Cervical } \\
\text { Screening }\end{array}$ & $\begin{array}{l}\text { Cholesterol } \\
\text { Screening }\end{array}$ & $\begin{array}{l}\text { Prostate } \\
\text { Screening }\end{array}$ & Colonoscopy & $\begin{array}{l}\text { Fecal Occult } \\
\text { Blood Test or } \\
\text { Endoscopy }\end{array}$ & $\begin{array}{l}\text { Any Kind } \\
\text { of } \\
\text { Screening }\end{array}$ \\
\hline \multirow[t]{12}{*}{ Christian } & General & & $00^{25,56}$ & $++^{61,62}$ & $+^{25}$ & $\begin{array}{r}0^{57} \\
-{ }^{59}\end{array}$ & & & & & \\
\hline & Catholic & & $\begin{array}{l}+^{53} \\
00^{26,27}\end{array}$ & $\begin{array}{l}0^{26} \\
-55\end{array}$ & $000^{26,27,55}$ & $\begin{array}{r}0^{46} \\
-59\end{array}$ & $\begin{array}{l}+27 \\
0^{23}\end{array}$ & $++^{27}$ & & & \\
\hline & Protestant & General & $\begin{array}{l}+^{56} \\
0^{26} \\
-23\end{array}$ & $0^{27}$ & $0^{27}$ & $0^{46}$ & +27 & +27 & & & \\
\hline & & Mainline & +26 & +26 & $0^{26}$ & & +23 & & & & \\
\hline & & Evangelical & $0^{26}$ & $0^{26}$ & $0^{26}$ & & $0^{23}$ & & & & \\
\hline & & Baptist & $0^{48}$ & & & & & & & & \\
\hline & & Methodist & $0^{48}$ & $+^{55}$ & $0^{55}$ & & & & & & \\
\hline & & Holiness & $0^{48}$ & & & & & & & & \\
\hline & & Presbyterian & & $+^{55}$ & $0^{55}$ & & & & & & \\
\hline & $\begin{array}{l}\text { Church of } \\
\text { Ireland }\end{array}$ & & & $+^{55}$ & $+^{55}$ & & & & & & \\
\hline & Pentecostal & & & & & -59 & & & & & \\
\hline & $\begin{array}{l}\text { Apostolic } \\
\text { sects }\end{array}$ & & & & & -59 & & & & & \\
\hline Jews & & & $\begin{array}{l}+27 \\
0^{26}\end{array}$ & $++^{26,27}$ & $\begin{array}{l}+^{27} \\
0^{26}\end{array}$ & & $\begin{array}{l}+^{27} \\
0^{23}\end{array}$ & $+^{27}$ & & & \\
\hline Muslims & & & $0^{25}$ & $\begin{array}{l}0^{61} \\
-30\end{array}$ & -25 & $\begin{array}{l}+^{57} \\
-46\end{array}$ & & & & & \\
\hline Buddhists & & & & $\begin{array}{l}+ \\
+^{6,30,61,62}\end{array}$ & & & & & & & \\
\hline Hinduist & & & & $0^{61}$ & & & & & & & \\
\hline
\end{tabular}




\begin{tabular}{|c|c|c|c|c|c|c|c|c|c|}
\hline Other & $00^{26,48}$ & $00^{26,30}$ & $\begin{array}{l}0^{26} \\
-57\end{array}$ & & $0^{23}$ & & & & \\
\hline \multicolumn{10}{|l|}{ Religiosity } \\
\hline & $\begin{array}{l}\text { Mammogram or } \\
\text { clinical breast } \\
\text { examination }\end{array}$ & $\begin{array}{l}\text { Pap } \\
\text { smear }\end{array}$ & $\begin{array}{l}\text { Self-breast } \\
\text { examination }\end{array}$ & $\begin{array}{l}\text { Cervical } \\
\text { screening }\end{array}$ & $\begin{array}{l}\text { Cholesterol } \\
\text { screening }\end{array}$ & $\begin{array}{l}\text { Prostate } \\
\text { screening }\end{array}$ & Colonoscopy & $\begin{array}{l}\text { Fecal Occult } \\
\text { Blood Test or } \\
\text { endoscopy }\end{array}$ & $\begin{array}{l}\text { Any kind } \\
\text { of } \\
\text { screening }\end{array}$ \\
\hline Religiosity (ref.: low) & $\begin{array}{l}+^{47} \\
0000^{26,27,48,54} \\
-25,52,58\end{array}$ & $\begin{array}{l}+2^{27} \\
0^{26} \\
-50\end{array}$ & $\begin{array}{l}+^{26} \\
0^{27} \\
-25\end{array}$ & & $\begin{array}{l}+^{44} \\
00^{23,45}\end{array}$ & $\begin{array}{l}+27 \\
0^{31}\end{array}$ & & & \\
\hline $\begin{array}{l}\text { Religious locus of health control (ref.: } \\
\text { no) }\end{array}$ & $\begin{array}{l}+^{54} \\
0^{58}\end{array}$ & & & & $0^{45}$ & & $0^{45}$ & & \\
\hline Being faith-driven (ref.: no) & & .50 & & & & & & & \\
\hline \multicolumn{10}{|l|}{ Religious attendance } \\
\hline & $\begin{array}{l}\text { Mammogram or clinical } \\
\text { breast examination }\end{array}$ & $\begin{array}{l}\text { Pap } \\
\text { smear }\end{array}$ & $\begin{array}{l}\text { Self-breast } \\
\text { examination }\end{array}$ & $\begin{array}{l}\text { Cervical } \\
\text { screening }\end{array}$ & $\begin{array}{l}\text { Cholesterol } \\
\text { screening }\end{array}$ & $\begin{array}{l}\text { Prostate } \\
\text { screening }\end{array}$ & Colonoscopy & $\begin{array}{l}\text { Fecal Occult Blood } \\
\text { Test or endoscopy }\end{array}$ & $\begin{array}{l}\text { Any kind of } \\
\text { screening }\end{array}$ \\
\hline Religious attendance (ref:: never) & $\begin{array}{l}++++26,29,49,60 \\
0000^{47,48,51,58}\end{array}$ & $\begin{array}{l}++^{26,29} \\
0^{49}\end{array}$ & $++^{26,29}$ & & $\begin{array}{l}++^{23,44} \\
0^{45}\end{array}$ & $+^{51}$ & $0^{45}$ & +49 & +28 \\
\hline Religious activities (ref:: sometimes) & & & & & $0^{44}$ & & & & \\
\hline $\begin{array}{l}\text { Congregational support (ref.: no health- } \\
\text { related discussions with church } \\
\text { members) }\end{array}$ & & & & & +45 & & & & \\
\hline $\begin{array}{l}\text { Being active in one's church (ref.: not } \\
\text { frequently) }\end{array}$ & $0^{47}$ & & & & & & & & \\
\hline Church health committee (ref.: no) & $0^{47}$ & & & & & & & & \\
\hline $\begin{array}{l}\text { Breast cancer as a focus of the church } \\
\text { health committee (ref.: no) }\end{array}$ & -47 & & & & & & & & \\
\hline
\end{tabular}

Notes: +: significant positive association; 0: no significant association; -: significant negative association. 


\section{Quality Assessment}

The $\mathrm{n}=27$ studies which were included in our final sample fulfilled between $80 \%$ and $100 \%$ of the criteria in total. However, among the categories "missing data", "sensitivity analysis" and "conflict of interest/funders", only $52 \%$, $74 \%$ and $67 \%$ of the studies met the requirements. Please consider Table 3 for further details.

\section{Religious Denomination}

Overall, $\mathrm{n}=15^{23,25-27,30,46,48,53,55-57,59-62}$ of the 27 studies included in our final sample reported an association between religious denomination and cancer screening utilization. Data came from the United States $(n=7)$, the United Kingdom $(\mathrm{n}=2)$, Palestine, Kenya, Nigeria, Zimbabwe, Malaysia, and Singapore. More than two thirds of the studies relied on a cross-sectional design $(n=11)$, the other ones $(\mathrm{n}=4)$ had a longitudinal approach. Regarding religious denominations, $\mathrm{n}=14$ studies investigated a (partly) Christian sample. . $3,25-27,46,48,53,55-57,59-62^{-20}$ Hereby, $\mathrm{n}=9$ studies looked at Catholicism as an independent subcategory. ${ }^{23,26,27,46,53,55,56,59,60}$ As Protestants are a relatively heterogeneous religious group that is divided into various subgroups, this denomination was handled quite differently among the studies: $\mathrm{n}=4$ investigated Protestants in general. ${ }^{46,53,56,60}$ In sum, $n=2$ studies differentiated between Mainline and Evangelical Protestants, ${ }^{23,26}$ one between Baptists, Methodists, and the Holiness movement ${ }^{48}$ and the other one between Presbyterians and Methodists. ${ }^{55}$ Finally, $\mathrm{n}=2$ studies regarded members of the Pentecostal movement, ${ }^{59,60}$ and $\mathrm{n}=1$ rated Apostolic sects as an independent subcategory. ${ }^{59}$ In addition, one study investigated members of the church of Ireland. ${ }^{55}$ Among other religious groups, $n=4$ articles included Muslims, ${ }^{30,46,57,61}$ the same number examined Jewish people, ${ }^{23,26,27} \mathrm{n}=3$ studies Buddhists, ${ }^{30,57,61}$ and $\mathrm{n}=1$ study Hinduists. ${ }^{61}$ Eventually, $\mathrm{n}=7$ studies explored the association between religious factors and the utilization of cancer screenings among members of other religions, ${ }^{23,26,30,48,57,59,61}$ and $\mathrm{n}=8$ studies for nonreligious people. ${ }^{23,26,27,46,48,56,60,62}$ Concerning preventive cancer screenings, $\mathrm{n}=7$ articles looked at mammograms or clinical breast examinations ${ }^{25-27,48,53,56,60}$ (ever: $\mathrm{n}=1,{ }^{25}$ during the last three and a half years: $\mathrm{n}=1,{ }^{56}$ during the last two years: $n=4,{ }^{26,27,53,60}$ during the last year: $n=1^{48}$ ), $\mathrm{n}=6$ studies examined the use of pap smears ${ }^{26,27,30,55,61,62}$ (actively attending it: $n=1,{ }^{55}$ passively attending it: $n=1,{ }^{55}$ during the last two years: $n=2,{ }^{26,27}$ ever performed: $\left.\mathrm{n}=3^{30,61,62}\right), \quad \mathrm{n}=4 \quad$ studies investigated self-breast examinations $^{25-27,55}$ (performing it monthly: $\mathrm{n}=1,{ }^{27}$ during the last three months: $n=1,{ }^{25}$ during the last two years: $\mathrm{n}=1,{ }^{26}$ performing it: $\mathrm{n}=1^{55}$ ), $\mathrm{n}=3$ articles examined cervical screening ${ }^{46,57,59}$ (performing it: $\mathrm{n}=1,{ }^{57}$ ever performed it: $\left.n=2^{46,59}\right), \quad n=2$ studies regarded cholesterol screening ${ }^{23,27}$ (during the last two years: $n=2^{23,27}$ ), and $\mathrm{n}=1$ study looked at prostate screening during the last two years. ${ }^{27}$

As indicated above, there is not much evidence concerning the relationship of specific combinations of religious denominations and types of cancer screenings. Generally, there are no combinations that are investigated by more than three studies: A detailed presentation that reports the evidence with respect to all combinations is provided in the Supplementary Material, where we also provide the relevant studies. In this place, we only aim to summarize the main findings.

All in all, there are 53 combinations between different Christian denominations and the utilization of different cancer screenings. 16 of them indicate a positive relationship, six a negative, and the remaining 31 a non-significant one. Regarding the distribution between the Christian confessions, there are 14 combinations that refer to Catholics. Three of them indicate a higher use, two a lower use, and nine a non-significant relationship. For all Protestant people, eight out of 23 combinations detect a positive relationship, and one of them a negative one. Here, it is worth mentioning that three out of four studies detected an increased utilization among Mainline Protestants, and four out of four a non-significant relationship regarding Evangelical Protestants. Nine combinations were examined with respect to Jewish people; six of them found an increased likelihood of utilization, and none of them a decreased one. Among the six combinations that considered Muslims, one found a higher likelihood and three a lower one. Buddhists were investigated among three combinations, of which two revealed an increased and one a decreased screening level. Eventually, all studies that examined Hinduists $(\mathrm{n}=1)$ and members of other religions $(n=7)$ did not reveal significant relationships with cancer screenings.

\section{Importance of Religion}

In total, $\mathrm{n}=13$ studies ${ }^{23,25-27,31,44,45,47,48,50,52,54,58}$ examined the relationship between the importance of religion, or the religiosity of an individual, and the utilization of preventive cancer screenings. $\mathrm{n}=10$ studies used data 


\section{PRISMA 2009 Flow Diagram}
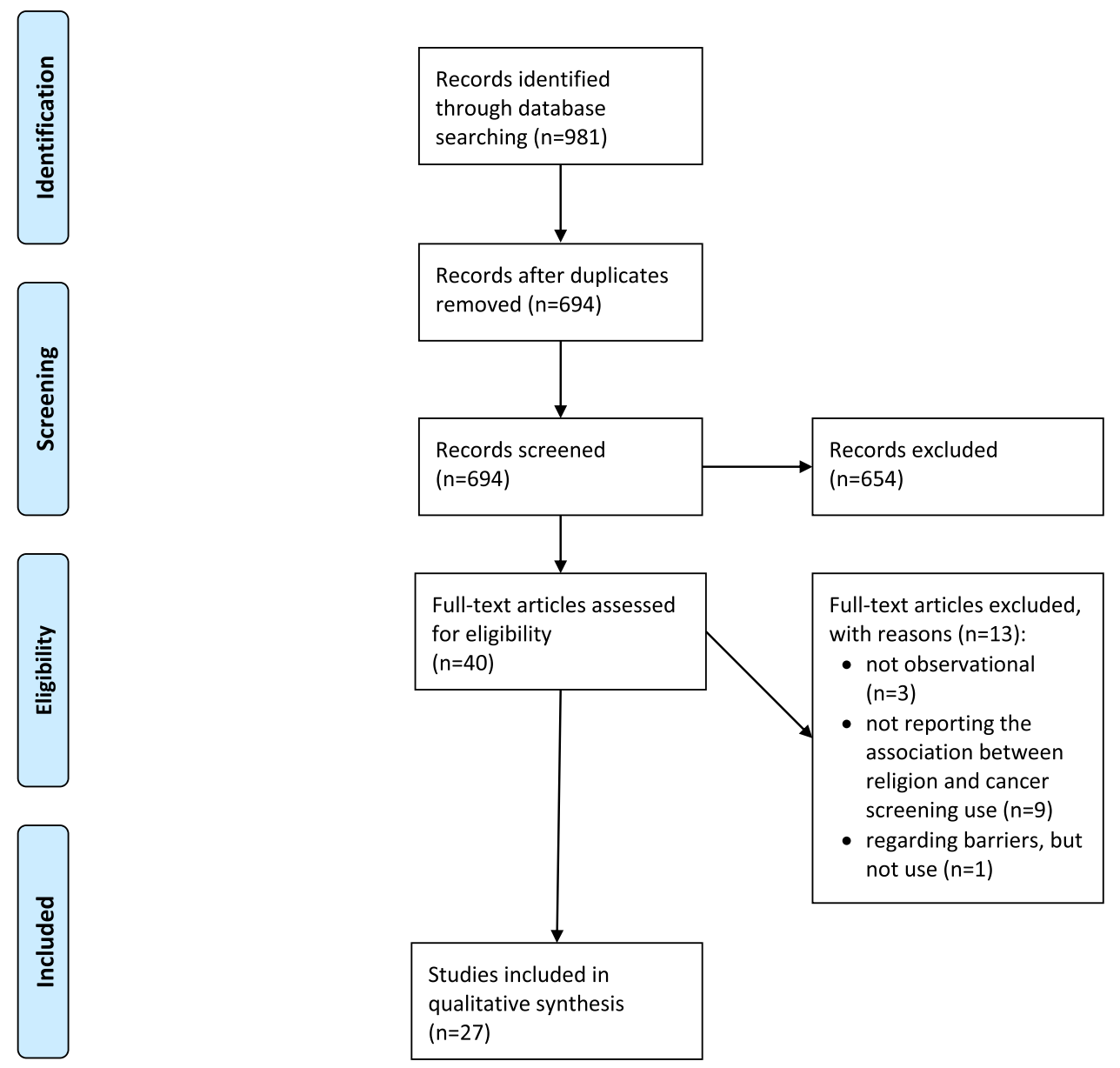

Figure I PRISMA flow diagram.

Notes: Adapted from: Moher D, Liberati A, Tetzlaff J, Altman DG; The PRISMA Group. Preferred Reporting Items for Systematic Reviews and Meta-Analyses: The PRISMA Statement. PLoS Med. 2009;6(7):el000097. doi:10.1371/journal.pmedI000097. ${ }^{43}$ Creative Commons. For more information, visit www.prisma-statement.org.

from the United States, $n=1$ study from Canada and $n=1$ from Mexico, so that most of the studies were placed in North America. Apart from that, $n=1$ study relied on data from Palestine. In total, $\mathrm{n}=7$ studies had a cross-sectional design, $n=6$ a longitudinal one. Only two studies used validated tools to quantify religiosity: Christman et $\mathrm{al}^{31}$ employed the Duke Religion Index, ${ }^{63}$ and Melvin et al the Multi-Dimensional Cultural Values Assessment Tool. ${ }^{64}$ Most of the other studies used a three-point scale $(n=6) ;^{23,26,27,44,48,58}$ one a two-point scale (dichotomous) $^{47}$ and another one a four-point scale. ${ }^{25}$ Benjamins et al and Mitchell regarded items that described the impact of one's religiosity on one's health beliefs. ${ }^{4,54}$ Lofters et al used principal components analysis to identify a profile that would apply to people being faith-driven, ${ }^{50}$ and Sen and Kumkale examined the religious locus of (perceived) health control. $^{58}$
Regarding cancer screenings, the studies investigated the use of mammograms or clinical breast examinations $(n=8)$ (during the last year: $n=3,{ }^{48,52,54}$ during the last two years: $n=3,{ }^{26,27,58}$ during the last two years and also the two years before: $n=1,47$ ever: $n=1^{25}$ ), cholesterol screenings $(n=4)$ (during the last two years: $\left.\mathrm{n}=4^{23,27,44,45}\right)$, pap smears $(\mathrm{n}=3)$ (during the last two years: $n=2,26,27$ during the last three years: $n=1^{50}$ ), selfbreast examinations $(n=3)$ (monthly: $n=1,27$ during the last three months: $n=1,{ }^{25}$ during the last two years: $n=1^{26}$ ), prostate screenings $(n=2)$ (during the last year: $\mathrm{n}=1,{ }^{31}$ during the last two years: $\mathrm{n}=1^{27}$ ), and colonoscopy $(n=1)\left(\right.$ ever: $\left.n=1^{45}\right)$.

Once more, the detailed results with respect to the relevant studies can be seen in the Supplementary Material. Regarding mammograms or clinical breast examinations, one out of seven studies detected 
Table 3 Quality Assessment

\begin{tabular}{|c|c|c|c|c|c|c|c|c|c|c|c|c|c|c|c|c|}
\hline $\begin{array}{l}\text { First } \\
\text { Author } \\
\text { (Year) }\end{array}$ & $\begin{array}{l}\text { Study } \\
\text { Objective }\end{array}$ & $\begin{array}{l}\text { Inclusion } \\
\text { and } \\
\text { Exclusion } \\
\text { Criteria }\end{array}$ & $\begin{array}{l}\text { Cancer } \\
\text { Screening } \\
\text { Description }\end{array}$ & $\begin{array}{l}\text { Data } \\
\text { Source }\end{array}$ & $\begin{array}{l}\text { Missing } \\
\text { Data }\end{array}$ & Statistics & $\begin{array}{l}\text { Consideration } \\
\text { of } \\
\text { Confounders }\end{array}$ & $\begin{array}{l}\text { Sensitivity } \\
\text { Analysis }\end{array}$ & $\begin{array}{l}\text { Sample } \\
\text { Size } \\
\text { (Subgroup) }\end{array}$ & Demographics & $\begin{array}{l}\text { Results } \\
\text { Discussed with } \\
\text { Respect to } \\
\text { Other Studies }\end{array}$ & $\begin{array}{l}\text { Results } \\
\text { Discussed } \\
\text { Regarding } \\
\text { Generalizability }\end{array}$ & Limitations & $\begin{array}{l}\text { Conclusion } \\
\text { Supported } \\
\text { by Data }\end{array}$ & $\begin{array}{l}\text { Conflict } \\
\text { of } \\
\text { Interest/ } \\
\text { Funders }\end{array}$ & $\begin{array}{l}\% \text { of } \\
\text { Criteria } \\
\text { Fulfilled } \\
\text { by Study }\end{array}$ \\
\hline $\begin{array}{l}\text { Azaiza } \\
(2010)^{25}\end{array}$ & $\checkmark$ & $\checkmark$ & $\checkmark$ & $\checkmark$ & & $\checkmark$ & $\checkmark$ & $\checkmark$ & $\checkmark$ & $\checkmark$ & $\checkmark$ & $\checkmark$ & $\checkmark$ & $\checkmark$ & $\checkmark$ & 93 \\
\hline $\begin{array}{l}\text { Benjamins } \\
(2004)^{27}\end{array}$ & $\checkmark$ & $\checkmark$ & $\checkmark$ & $\checkmark$ & $\checkmark$ & $s$ & $\checkmark$ & $\checkmark$ & $\checkmark$ & $\checkmark$ & & $\checkmark$ & & $\checkmark$ & & 80 \\
\hline $\begin{array}{l}\text { Benjamins } \\
(2005)^{23}\end{array}$ & $\checkmark$ & $\checkmark$ & $\checkmark$ & $\checkmark$ & $\checkmark$ & $\checkmark$ & $\checkmark$ & $\checkmark$ & $\checkmark$ & $\checkmark$ & $s$ & $\checkmark$ & $\checkmark$ & $\checkmark$ & & 93 \\
\hline $\begin{array}{l}\text { Benjamins } \\
(2006)^{26}\end{array}$ & $\checkmark$ & $\checkmark$ & $\checkmark$ & $\checkmark$ & $\checkmark$ & $s$ & $\checkmark$ & $\checkmark$ & $\checkmark$ & $\checkmark$ & $\checkmark$ & $\checkmark$ & $\checkmark$ & $\checkmark$ & & 93 \\
\hline $\begin{array}{l}\text { Benjamins } \\
(2007)^{44}\end{array}$ & $\checkmark$ & $\checkmark$ & $\checkmark$ & $\checkmark$ & $\checkmark$ & $s$ & $\checkmark$ & $\checkmark$ & $s$ & $\checkmark$ & $s$ & $\checkmark$ & $\checkmark$ & $\checkmark$ & & 93 \\
\hline $\begin{array}{l}\text { Benjamins } \\
(2011)^{45}\end{array}$ & $\checkmark$ & $\checkmark$ & $\checkmark$ & $\checkmark$ & $\checkmark$ & $s$ & $\checkmark$ & $s$ & $s$ & $\checkmark$ & $s$ & $\checkmark$ & $\checkmark$ & $\checkmark$ & & 93 \\
\hline $\begin{array}{l}\text { Christman } \\
(2014)^{31}\end{array}$ & $\checkmark$ & $\checkmark$ & $\checkmark$ & $\checkmark$ & $\checkmark$ & $s$ & & & $\checkmark$ & $\checkmark$ & $s$ & $\checkmark$ & $\checkmark$ & $\checkmark$ & $\checkmark$ & 87 \\
\hline $\begin{array}{l}\text { Dutta } \\
(2018)^{46}\end{array}$ & $\checkmark$ & $\checkmark$ & $\checkmark$ & $\checkmark$ & $\checkmark$ & $\checkmark$ & $\checkmark$ & & $\checkmark$ & $\checkmark$ & $\checkmark$ & $\checkmark$ & $\checkmark$ & $\checkmark$ & $\checkmark$ & 93 \\
\hline $\begin{array}{l}\text { Fox } \\
(1998)^{47}\end{array}$ & $\checkmark$ & $\checkmark$ & $\checkmark$ & $\checkmark$ & $\checkmark$ & $\checkmark$ & $\checkmark$ & $\checkmark$ & $\checkmark$ & $\checkmark$ & $\checkmark$ & $\checkmark$ & $\checkmark$ & $\checkmark$ & & 93 \\
\hline $\begin{array}{l}\text { Katz } \\
(2008)^{48}\end{array}$ & $\checkmark$ & $\checkmark$ & $\checkmark$ & $\checkmark$ & & $\checkmark$ & & & $s$ & $\checkmark$ & $\checkmark$ & $\checkmark$ & $\checkmark$ & $\checkmark$ & $\checkmark$ & 80 \\
\hline $\begin{array}{l}\text { Kretzler } \\
(2020)^{28}\end{array}$ & $\checkmark$ & $\checkmark$ & $\checkmark$ & $\checkmark$ & $\checkmark$ & $\checkmark$ & $\checkmark$ & $\checkmark$ & $\checkmark$ & $s$ & $\checkmark$ & $\checkmark$ & $\checkmark$ & $\checkmark$ & $\checkmark$ & 100 \\
\hline $\begin{array}{l}\text { Leyva } \\
(2015)^{49}\end{array}$ & $\checkmark$ & $\checkmark$ & $\checkmark$ & $\checkmark$ & & $\checkmark$ & $\checkmark$ & $\checkmark$ & $\checkmark$ & $\checkmark$ & $\checkmark$ & $\checkmark$ & $\checkmark$ & $\checkmark$ & $\checkmark$ & 93 \\
\hline $\begin{array}{l}\text { Lofters } \\
(2018)^{50}\end{array}$ & $\checkmark$ & $\checkmark$ & $\checkmark$ & $\checkmark$ & & $\checkmark$ & & & $\checkmark$ & $\checkmark$ & $\checkmark$ & $\checkmark$ & $\checkmark$ & $\checkmark$ & $\checkmark$ & 80 \\
\hline $\begin{array}{l}\text { McFall } \\
(2008)^{51}\end{array}$ & $\checkmark$ & $\checkmark$ & $\checkmark$ & $\checkmark$ & & $\checkmark$ & $\checkmark$ & & $\checkmark$ & $\checkmark$ & $\checkmark$ & $\checkmark$ & $\checkmark$ & $\checkmark$ & $\checkmark$ & 87 \\
\hline $\begin{array}{l}\text { Melvin } \\
(2016)^{52}\end{array}$ & $\checkmark$ & $\checkmark$ & $\checkmark$ & $\checkmark$ & & $\checkmark$ & $\checkmark$ & $\checkmark$ & $\checkmark$ & $\checkmark$ & $\checkmark$ & $\checkmark$ & $\checkmark$ & $\checkmark$ & $\checkmark$ & 93 \\
\hline $\begin{array}{l}\text { Miller } \\
(1993)^{53}\end{array}$ & $\checkmark$ & $\checkmark$ & $\checkmark$ & $\checkmark$ & & $\checkmark$ & $\checkmark$ & $\checkmark$ & $\checkmark$ & $\checkmark$ & $\checkmark$ & $\checkmark$ & $\checkmark$ & $\checkmark$ & $\checkmark$ & 93 \\
\hline
\end{tabular}




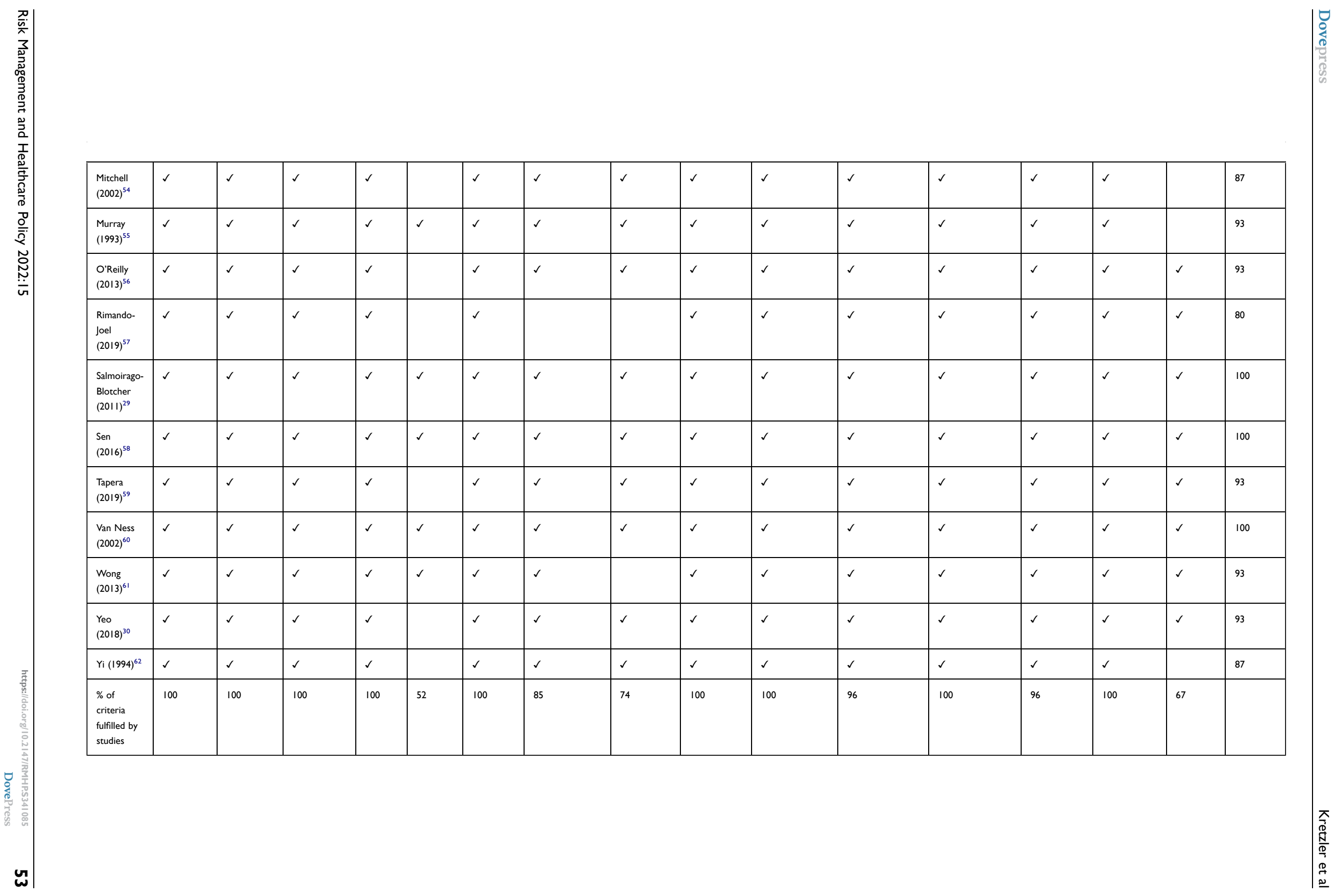


a positive relationship with religiosity, and two a negative one. Among self-breast examinations $(n=3)$ and pap smears $(n=3)$, one detected a positive and one a negative association. For cholesterol tests $(n=3)$ and prostate screenings $(n=2)$, there was one study, respectively, that detected an increased use in case of higher religiosity.

Finally, concerning the individuals that anticipated a religious locus of health control, one study found out that they had increased chances of mammogram or clinical breast examination uptake. For this kind of screening, again, and pap smears and colonoscopy, there was also one study, respectively, that revealed a non-significant relationship. Lastly, one article revealed a negative relationship between being faith-driven and the probability of pap smear utilization.

\section{Religious Attendance}

In total, $n=12$ studies examined the relationship between religious attendance and the use of preventive cancer screenings. $^{23,26,28,29,44,45,47-49,51,58,60}$ Once more, nearly all studies used data from the United States $(n=10)$, while $n=1$ study investigated a German sample, and $n=1$ a Mexican one. One half of the articles employed a crosssectional design $(n=6)$, the other one a longitudinal approach $(n=6)$. The frequency of religious attendance was measured on two-point scales (dichotomously) $\left(n=4^{44,47,51,60}\right)$, three-point scales $\left(n=2^{45,48}\right)$, four-point scales $\left(n=3^{29,49,58}\right)$, and five-point scales $\left(n=3^{23,26,28}\right)$. In sum, $n=1$ study investigated the frequency of participating in activities organized by one's church, rated on a threepoint scale, ${ }^{44}$ another one the role of congregational support, rated on a four-point scale, ${ }^{45}$ and a last one asked whether an individual was active in its church community, apart from just visiting worships (dichotomous). ${ }^{47}$ The same article also looked at the existence of a church health committee (dichotomous), and whether breast cancer was an important topic for such an institution (dichotomous). ${ }^{47}$ Concerning cancer screenings, the studies explored the utilization of mammograms or clinical breast examinations $(\mathrm{n}=8)$ (during the last year: $\mathrm{n}=1,{ }^{48}$ during the last two years: $n=5,{ }^{26,49,51,58,60}$ during the last two years and also the two years before: $n=1,47$ ever: $n=1^{29}$ ), cholesterol screenings $(n=3)$ (during the last two years: $n=3^{23,44,45}$ ), pap smears $(n=3)$ (during the last two years: $n=1,{ }^{26}$ during the last three years: $n=1,{ }^{49}$ ever: $\left.n=1^{29}\right)$, self-breast examinations $(n=2)$ (during the last two years: $n=1,{ }^{26}$ ever: $\left.n=1^{29}\right)$, colonoscopy $(n=1)$ (ever: $\left.n=1^{45}\right)$, prostate screening $(n=1)$ (during the last two years: $\left.n=1^{51}\right)$, either a Fecal
Occult Blood Test during the last year or an endoscopy during the last five years $(n=1),{ }^{49}$ and any cancer screening $(n=1)$ (during the last years: $n=1^{28}$ ).

All in all, $n=19$ combinations between religious attendance and cancer screenings were examined, and $n=13$ represented a positive relationship between these two. Meanwhile, the one study that investigated the impact of religious activities did not detect a significant relationship, and another one which considered congregational support revealed that this was negatively associated with the uptake of cholesterol screenings. Regarding the utilization of mammograms or clinical breast examinations, one study looked at the presence of a church health committee, which had no significant effect, and whether such a health committee had breast cancer as a priority topic. If this was the case, the article found out that the likelihood of mammogram or breast cancer screening uptake surprisingly decreased.

For detailed results, please consider the Supplementary Material.

\section{Discussion}

The aim of this systematic review was to summarize the evidence on the relationship between religion and the uptake of cancer screenings. Hereby, we included $n=27$ studies investigating that association. ${ }^{23,25-31,44-62}$

Regarding religious denomination and religiosity, there is inconclusive evidence on their link to cancer screening uptake. Compared to members of other religions or nonreligious individuals, (Protestant) Christians and Jews might have an increased probability of cancer screening use. However, except for these denominations, most of the studies revealed a non-significant role of religious memberships. With respect to religiosity, most investigations did not detect a significant association either. However, the studies that looked at religious attendance provided quite conclusive evidence: Eight out of twelve studies found a positive association between attending religious services and using any kind of cancer screening, and there was no study that revealed a negative relationship.

For a further examination of these three religious dimensions, a look at the three studies that included all of them in their statistical analysis ${ }^{23,26,48}$ might be useful. Once more, their results differ in several ways: Katz et al did not find a significant association for religious denominations, religiosity, or religious attendance. ${ }^{48}$ Benjamins revealed that increased religious attendance and being a Mainline Protestant was related to increased odds of 
cholesterol screening utilization, ${ }^{23}$ and Benjamins found being a Mainline Protestant or being Jewish, being religious, and attending religious services to be beneficial towards mammogram, pap smear of self-breast examination performance. ${ }^{26}$ Hereby, it should also be noted that Katz investigated a sample of low-income, rural Americans, while both studies by Benjamins used the nationally representative Health and Retirement study (United States).

Finally, it should also be mentioned that individuals with extremely high levels of religious attendance may not report increased screening rates (eg, compared to individuals with moderate levels of religious attendance), although higher religious attendance is generally associated with increased levels of cancer screening use. In Benjamin's (2006) examination of self-breast examination utilization and Kretzler's investigation that explored the use of all kinds of cancer screenings together, the fully adjusted model reveals a positive relationship that vanished at very high levels, like more often than once per week. ${ }^{26,28}$ However, there is a lack of studies that regard these high frequencies.

Overall, our review does not provide clear results with respect to religious denominations or religiosity but detects a strong tendency towards an increased use of cancer screening due to religious attendance. Previous research developed several pathways that describe how this factor can lead to higher cancer screening utilization. Firstly, worships also have a social dimension, as one gets in touch with a community. Such a social network increase was found to be positively associated with participation in gastric cancer screening, ${ }^{33}$ as well as social support in general. ${ }^{34}$ Secondly, the regular attendance at religious events might be linked to certain personality traits, like conscientiousness, which is also positively associated with the utilization of cancer screenings. ${ }^{35}$ Thirdly, as Benjamins hypothesized, it might be that these visits bring one in touch with the health care system, so that one gets to know the preventive screening opportunities and develops a perceived need to use them. ${ }^{23}$ This is also supported by studies that detect a low knowledge about cancer screenings among several populations. ${ }^{65}$ Finally, religious attendance was identified to be associated with higher purpose in life, ${ }^{24}$ which in turn may be related to a higher degree of cancer screening utilization. ${ }^{66}$

Referring to the comparability of the studies included in this systematic review, there are several restrictions, although most of the studies relied on North American data. First, the studies looked at different kinds of cancer screenings, like clinical breast examinations or pap smears. In addition, the recall period for the screenings differed, not only by type, but also from "ever used"45 to "monthly performed". ${ }^{27}$ The same was true for the assessment of religious denominations, especially Christians, which were summarized into one group ${ }^{25}$ or investigated in terms of up to four subgroups. ${ }^{55}$ Eventually, the samples were very heterogenous. While some studies relied on nationally representative samples, ${ }^{28}$ some others looked at specific populations, such as female church members. ${ }^{47}$

The heterogeneity of the samples affects the general cancer screening utilization levels besides from an influence due to religious factors. For example, women and older adults were found to have increased odds of undergoing cancer screenings. ${ }^{15,67}$ In addition, individuals with higher income and a better education are more likely to use preventive health services as well. ${ }^{16}$ As to psychosocial factors, optimism and higher self-esteem may be associated with a higher probability of participating in cancer screenings, while loneliness and social exclusion could be potential barriers to screening use. ${ }^{22}$

The contemplation of existing articles that examine the association between religion and the utilization of preventive cancer screenings may provide a few suggestions for future research. As already mentioned, most of the studies were conducted in the United States, and many of the remaining ones were from high-income countries as well. Especially for a proper comparison of the often cultural influence of religious denominations, it would be useful to have further evidence from other countries as well, as the influence of religion on society decreases particularly in industrial countries. ${ }^{68}$ Furthermore, only three out of 27 studies included all the roles of denomination, religiosity, and attendance in their statistical analysis. ${ }^{23,26,48}$ Moreover, further investigations on people that attend religious events very often, eg, more than once per week, would be useful, as the preliminary findings of the articles included in this systematic review point to a vanishing association with the increased cancer screening utilization. ${ }^{26,28}$ If this was really the case, then it might also explain why some studies did not reveal a clear role of religious attendance among preventive cancer screening use, as the people that attend the most form the exception to the rule. Finally, there were only two studies that investigated healthrelated factors of a church, such as the presence of a health committee. ${ }^{45,47}$ To elucidate the pathway 
between religious attendance and cancer screening attendance, more investigations of this kind might be helpful. Furthermore, all studies that investigate religious attendance rely on Christian individuals. Here, it would also be necessary to look at other religious denominations as well. Moreover, longitudinal studies in this area are required.

Some strengths and limitations of our systematic review are worth noting. To the best of our knowledge, this is the first systematic review that summarizes the evidence with respect to the influence of religion on the uptake of preventive cancer screenings. Thereby, it focuses on empirical studies that do not investigate specific samples, eg, populations with mental diseases. A quality assessment was performed by two reviewers, as study screening and data extraction, to prevent from bias and provide a high-quality report.

However, there are also some limitations that are wellworth mentioning. Initially, we abstained from carrying out a meta-analysis due to the heterogeneity between the studies. Thus, this decision is supported by recommendations that regard this matter and perceive incorrect estimations due these differences. ${ }^{69}$ In addition, we may not have exploited the full potential of the databases we employed, as we did not use MeSH headings (PubMed and CINAHL) or the thesaurus gadget (PsycINFO).

\section{Conclusion}

Overall, the findings of the studies included in this review point towards a positive association between religious attendance and cancer screening utilization. Regarding religious denomination or religiosity, the evidence is quite unclear. These results match previous findings about the importance of social factors for an adequate use of medical services. ${ }^{21,22}$ However, they do not point towards an influence of religion itself on the use of cancer screenings. In sum, this knowledge can help in identifying populations that are at risk of underuse of cancer screenings and therefore increase the ineffectively low screening rates.

Further research could lay its focus on examining the relationship in lower-income countries and refine their assessment of religion to clarify the influence of its different dimensions, such as denominations, religiosity, or religious attendance

\section{Funding}

There is no funding to report.

\section{Disclosure}

The authors report no conflicts of interest in this work.

\section{References}

1. Bray F, Ferlay J, Soerjomataram I, Siegel RL, Torre LA, Jemal A. Global cancer statistics 2018: GLOBOCAN estimates of incidence and mortality worldwide for 36 cancers in 185 countries. CA Cancer J Clin. 2018;68(6):394-424. doi:10.3322/caac.21492

2. Robert Koch-Institut, Gesellschaft der epidemiologischen Krebsregister in Deutschland e.V. Krebs in Deutschland 2007/2008; 2012 [Cancer in Germany 2007/2008]. Available from: https://www.rki.de/DE/Content/ Gesundheitsmonitoring/Gesundheitsberichterstattung/ GBEDownloadsB/KID2012.pdf?_blob=publicationFile. Accessed December 22, 2021.

3. Barnes B, Kraywinkel K, Nowossadeck E, et al. Bericht zum Krebsgeschehen in Deutschland 2016; 2016 [Report in Cancer Events in Germany 2016]. Available from: https://edoc.rki.de/bit stream $/$ handle $/ 176904 / 3264 / 28$ oaKVmif0wDk.pdf? sequence $=$ 1\&isAllowed=y. Accessed December 22, 2021.

4. World Health Organization. Prevention. Available from: https://www. who.int/health-topics/cancer\#tab=tab_2. Accessed January 08, 2021.

5. Leppin A. Konzepte und Strategien der Prävention [Concepts and Strategies of Prevention]. In: Hurrelmann K, Klotz T, Haisch J, editors. Lehrbuch Prävention und Gesundheitsförderung. Huber; 2010:35-44.

6. American Society of Clinical Oncology. 2007 update of recommendations for the use of tumor markers in breast cancer. $J$ Oncol Pract. 2007;3(6):336-339. doi:10.1200/jop.0768504

7. International Early Lung Cancer Action Program Investigators. Survival of patients with stage I lung cancer detected on CT screening. $N$ Engl J Med. 2006;355(17):1763-1771. doi:10.1056/ NEJMoa060476

8. Mandel JS, Bond JH, Church TR, et al. Reducing mortality from colorectal cancer by screening for fecal occult blood. Minnesota Colon Cancer Control Study. $N$ Engl J Med. 1993;328 (19):1365-1371. doi:10.1056/NEJM199305133281901

9. Spuling S, Ziegelmann J, Wünsche J. Was tun wir für unsere Gesundheit? Gesundheitsverhalten in der zweiten Lebenshälfte [What Do We Do For Our Health? Health Behavior During the Second Half of Life]. In: Mahne K, Wolff J, Simonson J, TeschRömer C, editors. Altern im Wandel. Zwei Jahrzehnte Deutscher Alterssurvey (DEAS). Deutsches Zentrum für Altersfragen (DZA); 2016.

10. Wilson JMG, Jungner G. Principles and Practice of Screening for Disease. Geneva: World Health Organization; 1968.

11. Deandrea S, Molina-Barcelo A, Uluturk A, et al. Presence, characteristics and equity of access to breast cancer screening programmes in 27 European countries in 2010 and 2014. Results from an international survey. Prev Med. 2016;91:250-263. doi:10.1016/j.ypmed.2016.08.021

12. Andersen R. Revisiting the behavioral model and access to medical care: does it matter? J Health Soc Behav. 1995;36(1):1-10. doi: $10.2307 / 2137284$

13. Beydoun HA, Beydoun MA. Predictors of colorectal cancer screening behaviors among average-risk older adults in the United States. Cancer Causes Control. 2008;19(4):339-359. doi:10.1007/s10552007-9100-y

14. Hsia J, Kemper E, Kiefe C, et al. The importance of health insurance as a determinant of cancer screening: evidence from the Women's Health Initiative. Prev Med. 2000;31(3):261-270. doi:10.1006/ pmed.2000.0697

15. Saß A, Wurm S, Ziese T. Inanspruchnahmeverhalten [Health Care Utilization]. In: Böhm K, Tesch-Römer C, Ziese T, editors. Beiträge zur Gesundheitsberichterstattung des Bundes. Gesundheit und Krankheit im Alter. Robert Koch-Institut; 2009. 
16. Bremer P, Wübker A. Soziale Ungleichheit und Inanspruchnahme medizinischer und präventiver Leistungen in Deutschland: eine empirische Analyse [Social Inequality and Utilization of Medical and Preventive Services in Germany: An Empirical Analysis]. Diskussionspapiere // Wirtschaftwissenschaftliche Fakultät, Universität Witten, Herdecke, No 20/2011. 2012.

17. Gorin SS, Heck JE. Cancer screening among Latino subgroups in the United States. Prev Med. 2005;40(5):515-526. doi:10.1016/j. ypmed.2004.09.031

18. Sieverding M, Matterne U, Ciccarello L. Gender differences in FOBT use: evidence from a large German survey. Z Gastroenterol. 2008;46 (Suppl 1):S47-51. doi:10.1055/s-2007-963489

19. Sieverding M, Matterne U, Ciccarello L, Luboldt HJ. [Early detection of prostate cancer in Germany. A study of a representative random sample of the population]. Urologe A. 2008;47(9):1233-1238. German. doi:10.1007/s00120-008-1695-4

20. Janz NK, Becker MH. The health belief model: a decade later. Health Educ Q. 1984;11(1):1-47. doi:10.1177/109019818401100101

21. Pearlman DN, Clark MA, Rakowski W, Ehrich B. Screening for breast and cervical cancers: the importance of knowledge and perceived cancer survivability. Women Health. 1999;28(4):93-112. doi:10.1300/J013v28n04_06

22. Hajek A, Bock JO, Konig HH. The role of general psychosocial factors for the use of cancer screening-Findings of a population-based observational study among older adults in Germany. Cancer Med. 2017;6(12):3025-3039. doi:10.1002/ cam4.1226

23. Benjamins MR. Social determinants of preventive service utilization: how religion influences the use of cholesterol screening in older adults. Res Aging. 2005;27(4):475-497. doi:10.1177/016402750 5276048

24. Chen Y, Kim ES, VanderWeele TJ. Religious-service attendance and subsequent health and well-being throughout adulthood: evidence from three prospective cohorts. Int $J$ Epidemiol. 2021;49 (6):2030-2040. doi:10.1093/ije/dyaa120

25. Azaiza F, Cohen M, Awad M, Daoud F. Factors associated with low screening for breast cancer in the Palestinian Authority: relations of availability, environmental barriers, and cancer-related fatalism. Cancer. 2010;116(19):4646-4655. doi:10.1002/cncr.25378

26. Benjamins MR. Religious influences on preventive health care use in a nationally representative sample of middle-age women. J Behav Med. 2006;29(1):1-16. doi:10.1007/s10865-005-9035-2

27. Benjamins MR, Brown C. Religion and preventative health care utilization among the elderly. Soc Sci Med. 2004;58(1):109-118. doi:10.1016/S0277-9536(03)00152-7

28. Kretzler B, Konig HH, Hajek A. Religious attendance and cancer screening behavior. Front Oncol. 2020;10:583925. doi:10.3389/ fonc. 2020.583925

29. Salmoirago-Blotcher E, Fitchett G, Ockene JK, et al. Religion and healthy lifestyle behaviors among postmenopausal women: the women's health initiative. $J$ Behav Med. 2011;34(5):360-371. doi:10.1007/s10865-011-9322-z

30. Yeo C, Fang H, Thilagamangai SSL, Shorey S, Shorey S. Factors affecting Pap smear uptake in a maternity hospital: a descriptive cross-sectional study. $J$ Adv Nurs. 2018;74(11):2533-2543. doi:10.1111/jan.13769

31. Christman LK, Abernethy AD, Gorsuch RL, Brown A. Intrinsic religiousness as a mediator between fatalism and cancer-specific fear: clarifying the role of fear in prostate cancer screening. $J$ Relig Health. 2014;53(3):760-772. doi:10.1007/s10943-012-9670-1

32. Li S, Stampfer MJ, Williams DR, VanderWeele TJ. Association of religious service attendance with mortality among women. JAMA Intern Med. 2016;176(6):777-785. doi:10.1001/jamainternmed. 2016.1615
33. Lee MH, Choi KS, Lee YY, Suh M, Jun JK. Relationship between social network and stage of adoption of gastric cancer screening among the Korean population. APJCP. 2013;14(10):6095-6101. doi:10.7314/apjcp.2013.14.10.6095

34. Bremer D, Ludecke D, von Dem Knesebeck O. Social relationships, age and the use of preventive health services: findings from the German ageing survey. Int J Environ Res Public Health. 2019;16 (21):4272. doi:10.3390/ijerph16214272

35. Aschwanden D, Gerend MA, Luchetti M, Stephan Y, Sutin AR, Terracciano A. Personality traits and preventive cancer screenings in the Health Retirement Study. Prev Med. 2019;126:105763. doi:10.1016/j.ypmed.2019.105763

36. Leyva B, Allen JD, Tom LS, Ospino H, Torres MI, Abraido-Lanza AF. Religion, fatalism, and cancer control: a qualitative study among Hispanic Catholics. Am J Health Behav. 2014;38(6):839-849. doi:10.5993/ajhb.38.6.6

37. Hou SI, Cao X. A systematic review of promising strategies of faith-based cancer education and lifestyle interventions among racial/ethnic minority groups. $J$ Cancer Educ. 2018;33 (6):1161-1175. doi:10.1007/s13187-017-1277-5

38. Shamseer L, Moher D, Clarke M, et al. Preferred reporting items for systematic review and meta-analysis protocols (PRISMA-P) 2015: elaboration and explanation. BMJ. 2015;350:g7647. doi:10.1136/bmj. g7647

39. Glock CY. On the study of religious commitment. Relig Educ. 1962;57(sup4):98-110. doi:10.1080/003440862057s407

40. Stuhldreher N, Konnopka A, Wild B, et al. Cost-of-illness studies and cost-effectiveness analyses in eating disorders: a systematic review. Int J Eat Disord. 2012;45(4):476-491. doi:10.1002/eat.20977

41. Hohls JK, Konig HH, Raynik YI, Hajek A. A systematic review of the association of anxiety with health care utilization and costs in people aged 65 years and older. J Affect Disord. 2018;232:163-176. doi:10.1016/j.jad.2018.02.011

42. King M. Measuring the religious variable: nine proposed dimensions. J Sci Stud Relig. 1967;6(2):173-190. doi:10.2307/1384044

43. Moher D, Liberati A, Tetzlaff J, Altman DG, Group P. Preferred reporting items for systematic reviews and meta-analyses: the PRISMA statement. PLoS Med. 2009;6(7):e1000097. doi:10.1371/ journal.pmed.1000097

44. Benjamins MR. Predictors of preventive health care use among middle-aged and older adults in Mexico: the role of religion. J Cross Cult Gerontol. 2007;22(2):221-234. doi:10.1007/s10823007-9036-4

45. Benjamins MR, Ellison CG, Krause NM, Marcum JP. Religion and preventive service use: do congregational support and religious beliefs explain the relationship between attendance and utilization? J Behav Med. 2011;34(6):462-476. doi:10.1007/ s10865-011-9318-8

46. Dutta T, Haderxhanaj L, Agley J, Jayawardene W, Meyerson B. Association between individual and intimate partner factors and cervical cancer screening in Kenya. Prev Chronic Dis. 2018;15: E157. doi:10.5888/pcd15.180182

47. Fox SA, Pitkin K, Paul C, Carson S, Duan N. Breast cancer screening adherence: does church attendance matter? Health Educ Behav. 1998;25(6):742-758. doi:10.1177/109019819802500605

48. Katz ML, Kauffman RM, Tatum CM, Paskett ED. Influence of church attendance and spirituality in a randomized controlled trial to increase mammography use among a low-income, tri-racial, rural community. J Relig Health. 2008;47(2):227-236. doi:10.1007/ s10943-008-9159-0

49. Leyva B, Nguyen AB, Allen JD, Taplin SH, Moser RP. Is religiosity associated with cancer screening? Results from a national survey. $J$ Relig Health. 2015;54(3):998-1013. doi:10.1007/s10943-0149843-1 
50. Lofters AK, Vahabi M, Pyshnov T, Kupets R, Guilcher SJT. Segmenting women eligible for cervical cancer screening using demographic, behavioural and attitudinal characteristics. Prev Med. 2018;114:134-139. doi:10.1016/j.ypmed.2018.06.013

51. McFall SL, Davila M. Gender, social ties, and cancer screening among elderly persons. J Aging Health. 2008;20(8):997-1011. doi:10.1177/0898264308324682

52. Melvin CL, Jefferson MS, Rice LJ, Cartmell KB, Halbert CH. Predictors of participation in mammography screening among non-hispanic black, non-hispanic white, and hispanic women. Front Public Health. 2016;4:188. doi:10.3389/fpubh.2016.00188

53. Miller AM, Champion VL. Mammography in women $>$ or $=50$ years of age. Predisposing and enabling characteristics. Cancer Nurs. 1993;16(4):260-269.

54. Mitchell J, Lannin DR, Mathews HF, Swanson MS. Religious beliefs and breast cancer screening. J Womens Health. 2002;11(10):907-915. doi:10.1089/154099902762203740

55. Murray M, McMillan C. Social and behavioural predictors of women's cancer screening practices in Northern Ireland. J Public Health Med. 1993;15(2):147-153.

56. O’Reilly D, Kinnear H, Rosato M, Mairs A, Hall C. Uptake of breast screening is influenced by current religion and religion of upbringing. $J$ Relig Health. 2013;52(4):1168-1176. doi:10.1007/s10943-0119556-7

57. Rimande-Joel R, Ekenedo GO. Knowledge, belief and practice of cervical cancer screening and prevention among women of Taraba, North-East Nigeria. APJCP. 2019;20(11):3291-3298. doi:10.31557/ APJCP.2019.20.11.3291

58. Sen CK, Kumkale GT. Who does not get screened? A simple model of the complex relationships in mammogram non-attendance. $J \quad$ Health Psychol. 2016;21(12):2838-2850. doi:10.1177/ 1359105315587138

59. Tapera O, Kadzatsa W, Nyakabau AM, et al. Sociodemographic inequities in cervical cancer screening, treatment and care amongst women aged at least 25 years: evidence from surveys in Harare, Zimbabwe. BMC Public Health. 2019;19(1):428. doi:10.1186/ s12889-019-6749-6
60. Van Ness PH, Kasl SV, Jones BA. Are religious women more likely to have breast cancer screening? J Relig Health. 2002;41(4):333-346. doi:10.1023/a:1021174426609

61. Wong YL, Chinna K, Mariapun J, et al. Correlates between risk perceptions of cervical cancer and screening practice. Prev Med. 2013;57(Suppl):S24-6. doi:10.1016/j.ypmed.2013.01.004

62. Yi JK. Factors associated with cervical cancer screening behavior among Vietnamese women. J Community Health. 1994;19 (3):189-200. doi:10.1007/BF02260379

63. Koenig H, Parkerson GR, Meador KG. Religion index for psychiatric research. Am J Psychiatry. 1997;154(6):885-886. doi:10.1176/ ajp.154.6.885b

64. Halbert CH, Barg FK, Guerra CE, et al. Cultural, economic, and psychological predictors of colonoscopy in a national sample. J Gen Intern Med. 2011;26(11):1311-1316. doi:10.1007/s11606011-1783-9

65. Forrester-Anderson IT. Prostate cancer screening perceptions, knowledge and behaviors among African American men: focus group findings. J Health Care Poor Underserved. 2005;16(4 Suppl A):22-30. doi:10.1353/hpu.2005.0122

66. Kim ES, Strecher VJ, Ryff CD. Purpose in life and use of preventive health care services. Proc Natl Acad Sci USA. 2014;111 (46):16331-16336. doi:10.1073/pnas.1414826111

67. Starker A, Saß A. Inanspruchnahme von Krebsfrüherkennungsun tersuchungen[Cancer Prevention Use]. Bundesgesundheitsblatt. 2013;56:858-867. doi:10.1007/s00103-012-1655-4

68. Inglehart R. Giving up on god: the global decline of religion. Foreign Affairs. 2020;99:110-118.

69. Egger M, Smith G, Schneider M. Systematic reviews of observational studies. In: Egger M, Smith G, Altman D, editors. Systematic Reviews in Health Care: Meta-Analysis in Context. Wiley; 2001.
Risk Management and Healthcare Policy

\section{Publish your work in this journal}

Risk Management and Healthcare Policy is an international, peerreviewed, open access journal focusing on all aspects of public health, policy, and preventative measures to promote good health and improve morbidity and mortality in the population. The journal welcomes submitted papers covering original research, basic science, clinical \& epidemiological studies, reviews and evaluations,

\section{Dovepress}

guidelines, expert opinion and commentary, case reports and extended reports. The manuscript management system is completely online and includes a very quick and fair peer-review system, which is all easy to use. Visit http://www.dovepress.com/testimonials.php to read real quotes from published authors. 